\title{
Problem Pembelajaran Pendidikan Agama Kristen Dimasa Pandemi terhadap Psikologi Anak
}

\author{
Darianti \\ Pascasarjana Magister Pendidikan Agama Kristen Sekolah Tinggi Teologi Real Batam \\ riantiria162@gmail.com \\ Talizaro Tafonao \\ Sekolah Tinggi Teologi Real Batam \\ talizarotafonao@gmail.com²
}

\begin{abstract}
The purpose of writing this article is to find out about the various problems that occur in the learning process during the Covid-19 pandemic. This study departs from the writer's anxiety about the presence of Covid-19 in Indonesia. The author observes empirically that Covid-19 has had a major impact on the psychology of children as explained in this article. This study uses the literature method with a descriptive qualitative approach. The analysis process carried out is to use various literary sources, both journals, books and other reliable reference materials to support the author's analysis related to the problems of learning Christian religious education during the pandemic. The results found in this study were efforts, tips and strategies in overcoming various problems, especially in dealing with children's psychology when learning was taking place by cooperating with parents and teachers in applying effective learning principles according to children's needs. Thus, Christian religious education has a very significant role in overcoming these various prolems.
\end{abstract}

Keywords:Problems; Education; Christianity; Psychology; Children; Pandemi.

\begin{abstract}
Abstrak
Tujuan penulisan artikel ini adalah untuk mengetahui tentang berbagai problem yang terjadi dalam proses pembelajaran dimasa pandemi covid-19. Kajian ini berangkat dari kegelisaan penulis terhadap kehadiran covid-19 di Indonesia. Penulis mengamati secara empiris bahwa covid-19 ini telah memberi dampak besar terhadap psikologi anak-anak sebagaimana penjelasan dalam artikel ini. Kajian ini menggunakan metode pustaka dengan pendekatan kualitatif deskriptif. Proses analisis yang dilakukan adalah menggunakan berbagai sumber literatur-literatur baik jurnal, buku dan bahan referensi lainnya yang terpercaya untuk mendukung analisis penulis yang berhubungan dengan problem pembelajaran pendidikan agama Kristen dimasa pandemi. Hasil yang ditemukan dalam kajian ini adalah adanya upaya, tips dan strategi dalam mengatasi berbagai problem khususnya dalam menangani psikologi anakanak pada saat pembelajaran berjalan dengan bekerjasama sama orang tua dan guru dalam menerapkan prinisp-prinsip pembelajaran yang efektif sesuai dengan kebutuhan anak. Dengan demikian bahwa pendidikan Agama Kristen memiliki peran yang sangat signifikan dalam mengatasi berbagai prolem tersebut
\end{abstract}

Kata Kunci: Problem; Pendidikan; Kristen; Psikolog; Anak, Pandemi 


\section{PENDAHULUAN}

Dunia pembelajaran sekarang berbeda dengan dunia pembelajaran dahulu, dimana pembelajaran harus berubah berhubungan keadaan dunia yang tidak kondusif, yaitu adanya wabah virus atau dikatakan pandemi yang mempengaruhi keadaan dunia, masyarakat, lingkungan bahkan dunia akademi. Sehingga semua pembelajaran juga harus dilaksanakan secara online untuk menjaga keselamatan anak-anak dari serangan virus tersebut. Salah satu upaya yang dilakukan oleh pemerintah dalam memutuskan mata rantai penyebaran covid-19 yakni mengeluarkan PP Nomor 21 tahun 2020 tentang Pembatasan Sosial Berskala Besar dalam Rangka Percepatan Penanganan Covid-19, ${ }^{1}$ sehingga hal ini terjadi pemutusan kegiatan sekolah supaya anakanak terhindar dari pandemi yang sangat mematikan ini. Peristiwa seperti ini membuat semua orang di segala tempat digoyahkan oleh virus atau penyakit yang menyebarkan ketakutan serta kecemasan di segala tempat. Informasi diperoleh melalui media sosial dimana banyak orang yang terpapar covid-19 dan meninggal. Pemerintah menginformasikan supaya masyarakat tetap menjaga kebersihan semua tubuh, seperti mencuci tangan, memakai masker, selalu siapkan sanitizer dan lain-lain,supaya dapat memutuskan penyebaran covid-19.2 Akhirnya penyakit atau virus yang menyebar keseluruh dunia

\footnotetext{
${ }^{1}$ (Kementrian KesehatanRI, 2020)

${ }^{2}$ Riska Dana Buana, "Analisis Perilaku Masyarakat Indonesia dalam Menghadapi Pandemi Covid-19 dan Kiat Menjaga Kesejahteraan Jiwa”, Sosial dan Budaya, Fakultas Syariah dan Hukum Universitas Islam Negeri (UIN) Syarif Hidayatullah Jakarta 53, no 9 (2017): 1689-1699.

${ }^{3}$ Ivan Muhammad Agung, "Memahami Pandemi Covid-19 Dalam Perspektif Psikologi Sosial", Psikobuletin:Buletin Ilmiah Psikologi 1, no 2
}

dengan cepat menjadi konsentrasi khusus, dimana pengaruhnya dapat dirasakan di masyarakat, keluarga, dan secara pribadi termasuk didalamnya psikis, psikologi dan mental. $^{3}$

Peristiwa yang terjadi menyebabkan keadaan dunia sampai merasakan kekacauan, maka dari itu covid-19 adalah musibah terbesar yang pernah terjadi seluruh dunia pengaruhnya dirasakan oleh seluruh kalangan masyarakat serta kendala politik, psikososial, ekonomi, dan sosial, pekerjaan begitu pula di bidang pendidikan. Penyebaran penyakit covid-19 pengaruhnya terasa di dunia pembelajaran. Informasi pelaksanaan pembelajaran yang dilakukan pemerintah untuk mencegah covid-19, maka kegiatan belajar disekolah dihentikan secara offline serta memberikan jalan keluarnya hanya dapat diselesaikan melalui media daring dengan menggunakan alat teknologi seperti, ponsel, komputer, laptop, tablet dan menggunakan data internet oleh karena itu perjumpaan yang dapat dilakukan dengan cara daring itu sesuai untuk mencegah percepatan proses virus covid-19. ${ }^{4}$ Keadaan yang mencemaskan terjadi disebabkan oleh pandemi covid-19 yang melanda dunia serta banyak penduduk merasakan ketakutan dan kecemasan dalam melewati hari-hari ini. Kekuatiran serta kegelisahan menguasai pikiran setiap orang karena belum ditemukan obat yang cocok untuk obat covid-19, sehingga menyebabkan psikologi, mental dan psikis terganggu. ${ }^{5}$

(2020): 68-84.

${ }^{4}$ Ahmad Syarifuddin, "Penerapan Model Pembelajaran Cooperative Belajar Dan FaktorFaktor Yang Mempengaruhinya", Ta'dib:Journal of Islamic Education (Jurnal Pendidikan Islam) 16, no 01 (2011): 113-136.

${ }^{5}$ Andi Thahir, "Psikologi Belajar Buku Pengantar dalamm Memahami Psikologi Belajar" (2014): 291. 
Chavez mengatakan pandemi ini merupakan peristiwa yang menimbulkan emosi negatif bagi setiap orang bahkan anak-anak yang mengalami tekanan secara psikologi. ${ }^{6}$ Dampak buruk dari pandemi ini dapat membuat pembelajaran tidak berjalan maksimal dan tidak semua anak fokus melakukan pembelajaran secara online. Dengan keadaan yang tidak memungkinkan untuk melakukan proses pembelajaran secara offline maka, proses pembelajaran secara onlinelah yang dapat dilakukan dari rumah masing-masing.

Proses pembelajaran yang dilakukan dari rumah saat ini sudah sangat tepat untuk dijalankan, agar penyebaran covid 19 dapat segera selesai. Di satu sisi bahwa pembelajaran online ini sangat mudah dilakukan tanpa harus hadir ditepat atau tatap muka antara guru serta siswa secara langsung. Model pembelajaran seperti ini ada plus-minusnya, apabila jaringan internet memadai maka peserta didik fokus pada pembelajaran tetapi jika jaringan internet tidak memadai, maka peserta didik tidak bisa mengerti pelajaran dengan baik, bahkan orang tua semakin sibuk dengan kegiatan peserta didik seperti ini karena harus mendampingi apabila pembelajaran sedang berlangsung. Dengan demikian orang tua mendapat beban dengan bermacam bahan pembelajaran yang perlu dipahami menuntut mereka dapat/sanggup mengerjakannya. ${ }^{7}$

Hal ini, menjadi kendala bagi orang tua bila harus menguasai semua pelajaran

\footnotetext{
${ }^{6}$ Chavez PhelpsıLinda L. Sperry, "Children and the COVID-19 Pandemic", Psychological Trauma:

Theory, Research, Practice, and Policy 12 (2020): 73-75.

${ }^{7}$ Nika CahyatiıRita Kusumah, "Peran Orang Tua Dalam Menerapkan Pembelajaran Di Rumah Saat Pandemi Covid 19", Jurnal Golden Age, Universitas Hamzanwadi 04, no 1 (2020): 152159.
}

yang dikirim oleh guru melalui media sosial. Kendala-kendala yang dialami orang tua dalam mendampingi anak belajar di rumah meliputi kurangnya pemahaman materi oleh orang tua, kesulitan orang tua dalam menumbuhkan minat belajar anak, tidak memiliki cukup waktu untuk mendampingi anak karena harus bekerja, orang tua tidak sabar dalam mendampingi anak saat belajar di rumah, kesulitan orang tua dalam mengoperasikan gadget, dan kendala lain terkait dengan jangkauan layanan internet. Hal senada dikatakan oleh Anita bahwa pembelajaran yang dilakukan dirumah dengan bimbingan orang tua memiliki beberapa kendala, sehingga tidak sedikit orang tua yang meminta pihak sekolah untuk dapat dengan segera melaksanakan pembelajaran secara tatap muka. ${ }^{8}$ Oleh karena itu, dalam pelaksanaan daring ini ternyata orang tua memiliki banyak kendala dalam mendampingi anak belajar di rumah. Begitu pula menurut Astita "Orang tua adalah orang yang menjadi panutan bagi anak-anaknya, karena setiap anak mula-mula mengagumi orang tuanya semua tingkah orang tuanya ditiru oleh anak-anaknya". 9 Orang tua sebagai pendidik yang utama dan yang pertama dalam sebuah keluarga. orang tua disebut pendidik utama karena besar sekali pengaruhnya dalam kehidupan setiap anak, sedangkan menurut Cahyati dan Kusumah bahwa orang tua mengatakan rasa berat bila anak-anak belajar dari rumah, apabila anak berada di rumah mereka berpikir bukan

\footnotetext{
${ }^{8}$ Anita WardaniıYulia Ayriza, “Analisis Kendala Orang Tua dalam Mendampingi Anak Belajar di Rumah Pada Masa Pandemi Covid-19”, Jurnal Obsesi : Jurnal Pendidikan Anak Usia Dini 5, no 1 (2020): hal 778 (772-782).

${ }^{9}$ NS Khalimah, "Peran orang tua dalam pembelajaran daring di mi darul ulum pedurungan kota semarang tahun pelajaran 2020/2021 skripsi” (2021).
} 
saatnya belajar melainkan hanya main, karena dianggap libur sekolah seperti keadaan pandemi ini. ${ }^{10}$ Berdasarkan penjelasan di atas bahwa pembelajaran sekarang yang menjadi pendidik utama di rumah adalah orang tua dengan segala keterbatasan yang mereka miliki, harus bertanggung jawab atas pendidikan anakanak di masa pandemi ini.

Selain itu, dalam pengamatan penulis secara empiris melihat bahwa proses pembelajaran di masa pandemi ini memunculkan masalah baru yaitu sulitnya pelaksanaaan pembelajaran Pendidikan Agama Kristen kepada peserta didik dimasa pandemi ini, sehingga hal itu mengganggu psikologi anak dalam pembelajaran. Berdasarkan sumber yang diperoleh penulis pada hari selasa 27 April 2021, jam 14.00 Wib pembicaraan melalui telpon dengan seorang anak bernama Petrick umur 14 tahun bahwa pembelajaran secara online mengalami gangguan pada dirinya cepat stress, tidak semangat, tidak fokus, cepat marah dan tidak puas, demikain juga pembicaraan pada hari kamis 28 April 2021, jam 10.30 Wib melalui telpon dengan seorang anak bernama Daniel umur 12 tahun, mengatakan mengalami gangguan pikiran dengan cepat marah, tidak fokus. Dia lebih suka pembelajaran secara offline karena lebih fokus dan mendapatkan penjelasan pembelajaran lebih baik. Begitu pula pembicaraan pada hari kamis 27 Mei 2021, jam 15.30 wib dengan seorang anak bernama Cathelien umur 13 tahun, mengatakan belajar online membuat tidak happy, sakit kepala, sakit mata, terlalu lama melihat layar laptop atau tablet, tidak bisa berinteraksi dengan teman dan guru. Sedangkan menurut Dimas anak umur 12 tahun pembicaraan jam 10.46 wib, belajar

${ }^{10}$ CahyatiıKusumah, "Peran Orang Tua Dalam Menerapkan Pembelajaran Di Rumah Saat online tidak mudah karena tidak mempunyai handphone android, laptop dan tablet, dan kuota internet untuk belajar online. Orang tua saya 1 (satu) minggu sekali ke sekolah mengambil materi pembelajaran dan tugas sekolah supaya dapat dikerjakan di rumah, lanjut Dimas mengatakan adapun handphone orang tua hanya biasa (bukan handphone android) untuk komunikasi saja. padahal kondisi seperti sekarang ini tidak memperbolehkan orang untuk datang ke sekolah, karena terkendala gawai, orang tua harus datang mengambil bahan dan tugas sekolah.

Berdasarkan pembicaraan di atas, menurut penulis bahwa pembelajaran secara online tidak maksimal dalam proses pembelajaran dengan beragam masalah yang dihadapi oleh anak-anak.

Akibat lain yang dialami, pembelajaran semakin tidak maksimal kurangnya sarana belajar seperti handphone, laptop, tablet, telpon pintar dan komputer pribadi ada pun punya orang tua itu terbatas, karena orang tua juga menggunakannya. Kalau pun ada sarana belajar handphone, laptop dan komputer tidak semua peserta didik bisa fokus mengikuti pembelajaran secara daring/online. Dan tidak hanya itu terjadi, tetapi pesan pembelajaran pendidikan Agama Kristen tidak dapat tersampaikan dengan baik. Oleh karena itu peran orang tua dalam mendampingi kesuksesan anak sepanjang belajar di rumah menjadi sangat sentral. Dengan berbagai panduan serta tips kepada orang tua agar lebih konstruktif dalam mendampingi anak selama belajar di rumah di masa pandemik. Sebelum adanya pandemi, kegiatan orang tua awalnya hanya sebagai pembimbing, mengarahakan serta menyediakan keperluan anak setiap hari.

Pandemi Covid 19”. 
Tetapi aktivitas ini tidak seperti itu lagi sebagaimana yang terjadi sekarang ini bahwa proses pembelajaran orang tua terlibat sepenuhnya dalam mendampingi dan mendidik anak-anak di rumah. ${ }^{11}$ Secara tidak langsung bahwa pendidikan diawali dari rumah. Dalam pelaksanaan pendidikan merupakan tanggung jawab orang tua dan masyarakat sekitar, tidak hanya tanggung jawab lembaga pendidikan saja. ${ }^{12}$ Jadi ada upaya dan kerja sama orang tua dalam mewujudkan pembelajaran yang baik selama masa pandemik.

Berdasarkan penjelasan tersebut, menurut penulis bahwa proses belajar mengajar bisa berjalan efisien serta efektif dengan didukungnya keterlibatan orang tua dalam mendampingi anak saat pembelajaran online sedang berlangsung. Proses pembelajaran yang diciptakan oleh guru agar tujuan meningkatkan kreativitas untuk berfikir para peserta didik sehingga keahlian berfikir pula bertambah. ${ }^{13}$ Proses pembelajaran yang diharapkan bisa ditingkatkan melalui pengetahuan baru sebagai upaya meningkatkan kemampuan yang lebih maksimal dalam model pembelajaran daring ini.

Dalam pengamatan penulis bahwa pembelajaran Pendidikan Agama Kristen mengalami kesulitan bagi peserta didik seperti sekarang ini (masa pandemi). Dimana peserta didik tidak dapat menerima pembelajaran dengan baik, diakibatkan berbagai faktor yang tidak mendukung seperti tempat tinggal yang tidak memiliki akses internet dll, peserta didik bosan dengan akitivitas online setiap hari mereka

\footnotetext{
${ }^{11}$ Khalimah, "Peran orang tua dalam pembelajaran daring di mi darul ulum pedurungan kota semarang tahun pelajaran 2020/2021 skripsi”. yang Sekolah dari Rumah”, 2020.
}

tidak dapat berinteraksi secara fisik. Keadaan seperti ini sangat mengganggu keadaan peserta didik secara psikologis. ${ }^{14}$ Oleh karena itu, berdasarkan latar belakang di atas, maka rumusan masalah dalam kajian ini adalah bagaimana caranya menangani problem pembelajaran pendidikan agama Kristen dimasa pandemi? Apa tips yang dapat digunakan? Bagaimana upaya-upaya orang tua dapat menangani psikologi anak? Dengan demikian maka tujuan dari kajian ini adalah untuk mengetahui problem yang terjadi dalam proses pembelajaran pendidikan Agama Kristen dimasa pandemi covid-19 terhadap psikologi anak.

\section{METODE PENELITIAN}

Penulisan artikel ini menggunakan metode pustaka dengan pendekatan kualitatif deskriptif. ${ }^{15}$ Dimana penggunaan metode ini dengan cara menganalisis, menjabarkan informasi dan data yang didapatkan berdasarkan berbagai literatur yang di analisis secara kualitatif deskriptif. Kajian pun dilakukan untuk melihat perkara yang sama dari dua sudut pandang yang berbeda. Hasilnya akan berupa sebuah kesimpulan bersama tentang Problem Pembelajaran Pendidikan Agama Kristen di Masa Pandemi Terhadap Psikologi Anak. Menurut Nazir, tata cara deskriptif ialah sesuatu tata cara dalam mempelajari status sekelompok manusia, sesuatu benda, sesuatu keadaan, sesuatu sistem pemikiran maupun sesuatu kelas kejadian pada masa

\footnotetext{
${ }^{14}$ Thahir, "Psikologi Belajar Buku Pengantar dalamm Memahami Psikologi Belajar". ${ }^{15}$ Sonny Eli Zaluchu, "Strategi Penelitian Kualitatif dan Kuantitatif di dalam Penelitian Agama", Evangelikal: Jurnal Teologi Injili dan Pembinaan Warga Jemaat 4, no 1 (2020): 28-38.
} 
kini. ${ }^{16}$ Penulis melakukan kajian terhadap sumber-sumber pustaka yang berhubungan dengan Problem Pembelajaran Pendidikan Agama Kristen dimasa Pandemi terhadap psikologi Anak, kemudian penulis menguraikan dalam kajian yang didsarakan dari berbagai sumber dan literatur (buku, jurnal dan wawancara).

\section{HASIL DAN PEMBAHASAN}

\section{Problem Pembelajaran Pendidikan Agama Kristen Dimasa Pandemi}

Belajar sesungguhnya merupakan interaksi antara guru dan murid. Itulah sebabnya Setiawan mendefinisikan bahwa pendidikan merupakan usaha sadar dan terencana untuk mewujudkan suasana belajar dan proses pembelajaran agar peserta didik aktif mengembangkan potensi dirinya. ${ }^{17}$ Di sisi lain ada problem yang dihadapi sebagai hambatan yang wajib dipecahkan supaya ada jalan keluarnya, hal ini dapat dikatakan permasalahan ialah kesenjangan antara realitas dengan sesuatu yang diharapkan lebih baik, supaya tercapai dengan hasil optimal. ${ }^{18}$ Dengan demikian bahwa problem pembelajaran merupakan proses interaksi antara peserta didik dan lingkungannya yang perlu diselesaikan, sehingga terjalin interaksi pembelajaran kearah yang lebih baik. Oleh karena itu pembelajaran merupakan aktivitas siswa untuk menggapai tujuan yang lebih

\footnotetext{
${ }^{16}$ Wahyudin Darmalaksana, "Metode Penelitian Kualitatif Studi Pustaka dan Studi Lapangan", Preprint Digital Library UIN Sunan Gunung Djati Bandung (2020): 1-6.

${ }^{17}$ Deny Setiawan, "Peran Pendidikan Karakter Dalam Mengembangkan Kecerdasan Moral", Jurnal Pendidikan Karakter 1, no 1 (2013): 53-63.

${ }^{18}$ Muhammad Rosihuddin, "Pengertian Problematika Pembelajaran"”, 2012.

${ }^{19}$ Tindhi Kinasih, "Manajemen Peningkatan

Kemampuan Guru PAI Dalam Penggunaan Metode
}

maksimal. Kinasih mengatakan pembelajaran adalah seperangkat kegiatan eksternal dalam belajar yang dirancang buat menunjang terjadinya semua proses belajar-mengajar yang bersifat internal. ${ }^{19}$ Oleh sebab itu, pembelajaran ialah kejadian atau pun suasana yang terencana untuk merancang pembelajaran dalam rangka menolong serta memudahkan proses pembelajaran, sehingga harapan bisa membangun semangat siswa.

Dengan jelas bahwa pembelajaran ialah kegiatan yang sangat utama. Perihal ini, maka keberhasilan seseorang dalam pencapaian sebuah tujuan pembelajaran yang layak, tergantung pada pendidikan bias berlangsung secara efisien atau tidak. Pendidikan ialah sesuatu proses yang dicoba dengan membagikan pembelajaran serta pelatihan yang diberikan kepada peserta didik untuk menggapai hasil belajar. Hutapea mengatakan pembelajaran adalah hasil proses belajar melalui bermacam pemahaman serta pengetahuan, uraian, perilaku serta tingkah laku, keahlian, kecakapan, energirespon, energi penerimaan serta aspek terdapat orang yang belajar. ${ }^{20}$ Sedangkan menurut Junier pembelajaran ialah sesuatu upaya yang dicoba oleh seorang dalam menguasai dan menginterpretasikan sesuatu pendidikan supaya lebih membangun kemampuan dan sikap. ${ }^{21}$ Dalam hal ini, proses pembelajaran serta pendidikan ialah tindakan yang dilakukan mendasari cara pendidik untuk

Pembelajaran Di SMP Negeri 1 Nusawungu Kecamatan Nusawungu Kabupaten Cilacap" (IAIN Purwokerto, 2018).

${ }^{20}$ Rinto Hasiholan Hutapea, "Kreativitas Mengajar Guru Pendidikan Agama Kristen Di Masa Covid19", Didache: Journal of Christian Education 1, no 1 (2020): 1.

${ }^{21}$ Junier Sakerebau, "Memahami Peran Psikologi Pendidikan Bagi Pembelajaran", BIA': Jurnal Teologi dan Pendidikan Kristen Kontekstual 1, no 1 (2018): 96-111. 
proses pembelajaran supaya dapat berfungsi sebagai orang yang mentransfer pengetahuan kepada peserta didik. ${ }^{22}$

Berdasarkan pemahaman di atas, maka proses pembelajaran yang dilakukan oleh pendidik mempunyai tugas dalam meningkatkan kemampuan dan membentuk perilaku serta sikap anak kearah lebih baik meliputi pengetahuan, moral, keahlian serta yang lainnya. Sebaliknya kemampuan seseorang untuk memperoleh pengajaran serta mempunyai kedudukan yang dapat memberi pengaruh terhadap lingkungan tempat tinggal. Oleh karena itu pembelajaran merupakan upaya yang dipakai untuk meningkatkan keahlian dan kemampuan yang dipunyai peserta didik. Dalam dunia pembelajaran pendidik hanya mengajar sumber pengetahuan, interaksi dan komunikasi yang mengarahkan ke hal yang positif dalam pembelajaran. Sebaliknya pendidik juga menjadi panutan serta penyambung komunikasi yang memiliki pemikiran inovatif serta bervariatif. ${ }^{23}$ Sebagai seorang guru harus memiliki strategi yang mampu menciptakan suasana baru dalam pembelajaran serta dapat menarik semangat peserta didik untuk mengikuti pelajaran seperti Pendidikan Agama Kristen dimasa pandemi ini. Karena pendidikan Agama Kristen sangat penting diajarkan kepada peserta didik, apalagi keadaan dunia dan sekitarnya yang tidak kondusif. ${ }^{24}$ Supaya peserta didik semakin hidup takut akan Tuhan dan tidak takut dengan lingkungan sekitarnya yang selalu memberitakan

\footnotetext{
שם.22.

${ }^{23}$ Ita Tri Puspita Wati, "Implementasi Kegiatan Belajar Mengajar Pada Sekolah Inklusif di SMPN 29 Surabaya", Jurnal Pendidikan 1, no 1 (2013): 110.

${ }^{24}$ Hermanto Sihotang, "Penggunaan Media
}

berita-berita yang menakutkan seperti berita tentang pedemi covid-19.

\section{Problem yang dihadapi Para Guru dalam Menyampaikan Pembelajaran di Masa Pandemi}

Memiliki profesi sebagai guru tidaklah tanpa permasalahan, profesi guru ialah profesi yang memerlukan inovasi, kreativitas, serta visi. Tetapi demikian guru, wajib dapat keluar dari seluruh berbagai kasus tersebut, pemecahan yang dikerjakan ialah opsi yang tidak merugikan guru sekalian jadi obat untuk siswa dalam proses belajar. Untuk proses belajar online sepanjang covid-19 belum berakhir, maka ada halangan yang dihadapi para pendidik saat mengajar, pelajaran yang tadinya tatap muka karena adanya covid-19 semua kegiatan belajar berubah secara daring. Hambatan yang dihadapi dalam proses belajaran online walapun letak rumah belum dapat jangkuan jaringan untuk online, data internet tidak mencukupi, tidak semua peserta didik memiliki handphone, komputer, laptop, tablet, smartphone dan alat belajar yang dipakai pendidik masih monoton, sehingga hasil yang diperoleh peserta didik mengalami jemu. Dimana pola pembelanjaran yang tidak interaktif, perilaku serta karakter para murid sulit dipantau, pembelajarannya lebih banyak tugas online. Pembelajaran secara online tidak dapat dipantau oleh guru dengan baik dan murid tidak dapat menyerap pelajaran dengan baik seperti pembelajaran tatap muka. ${ }^{25}$ Walaupun situasi pendidikan yang

Teknologi Informasi dalam Pembelajaran Pendidikan Agama Kristen di Masa Pandemi Covid-19", IMMANUEL: Jurnal Teologi dan Pendidikan Kristen 1, no 2 (2020): 63-75.

${ }^{25}$ Firman FirmanıSari Rahayu, "Pembelajaran Online di Tengah Pandemi Covid-19", Indonesian 
diterapkan sekarang berbeda, itu tidak mengurangi nilai belajar anak. Penilaian pembelajaran merupakan hasil yang diperoleh melalui perubahan tingkah laku dan kecerdasan anak dalam belajar berkreativitas, kreatif, inovatif serta pengalamannya. ${ }^{26}$ Bisa dibilang hasil pembelajaran mengalami peningkatan dari yang tidak bisa menjadi bisa. Apabila maksud pembelajaran bisa dicapai dengan maksimal, kemudian nilai belajar disebut nilai yang sukses diperoleh anak.

Keputusan pembelajaran di lembaga pendidikan mengalami perbedaan dengan nilai pembelajaran di rumah, karena ini hampir 1 (satu) tahun lebih metode pembelajaran di rumah disebabkan oleh covid-19. Ada sejumlah besar orang menyebutkan bahwa belajar dari rumah tidak berkesan. Perjumpaan melalui lembaga pendidikan dapat mengarahkan siswa dengan baik dari pada di rumah. Tiap-tiap masalah pasti ada jalan keluarnya, maka seorang pendidik dapat menjadi penggerak, penengah, dan fasilitator untuk mendefinisikan setiap proses pembelajaran di luar sekolah.

Keputusan belajar yang guru peroleh melalui lembaga pendidikan dapat dilihat dari pembentukan, kecerdasan, keahlian dan tingkah laku. Kecerdasan dan pengetahuan yang disebut kognitif. Kognitif merupakan kemampuan untuk menguraikan, memaparkan, merangkumkan dengan baik petunjukpetunjuk maksud pembelajaran dari hasil yang diperoleh melalui pemahaman pelajaran. $^{27}$ Kemampuan fisik dan

\footnotetext{
Journal of Educational Science (IJES) 2, no 2 (2020): 81-89.

${ }^{26}$ (Sadikin, 2020)

${ }^{27}$ S Mahmudah, R, "Pengaruh pembelajaran daring terhadap psikologis siswa terdampak social distancing akibat covid-19", Jurnal Al-Mau'izhoh Vol. 2. No, no 1 (2020): 207-213.
}

keterampilan disebut psikomotor yang merupakan keahlian siswa untuk menunjukan cara bahwa anak dapat meniru segala sesuatu, menciptakan, mempengaruhi dan mengarahkan, jadi saat anak bisa melakukan semuanya berarti anak memiliki kompetisi yang harus ditonjolkan dalam dirinya. Oleh karena itu psikomotor menerapkan hal yang berhubungan dengan fisik dan kemampuan yang dapat dipunyai. Sikap dan prilaku yang disebut afektif adalah respon yang terjadi pada anak untuk dapat menjawab setiap pertanyaan yang diajukan guru padanya dan memiliki cara berpikir yang luas, dapat mengeluarkan pendapat. Sedangkan belajar dari rumah akan terlihat juga hasilnya melalui Kognitif yaitu sesuai dengan pola pembelajaran sekarang murid harus aktif menunjukan kopetensinya sekalipun metode pembelajaran menggunakan alat teknologi seperti handphone, tablet, laptop dan komputer yang dilengkapi dengan program-program yang dapat digunakan untuk mengirim tugas sekolah, yaitu youtube, zoom meeting, telegram, whatsapp, google class room dan email. Begitu juga siswa dapat memaparkan hasil belajar yang diberikan oleh gurunya melalui pesan suara kemudian siswa akan menjawab dan memberikan jawabannya melalui pesan suara serta video. ${ }^{28}$ Kemampuan atau psikomotor yang ditunjukan siswa bahwa dia dapat menerima pelajaran dengan baik walaupun proses belajar melalui media online tidak mengurangi semangat mereka belajar seperti di sekolah secara offline, mereka

\footnotetext{
${ }^{28}$ Prilly ManuputtyıNovia Lakoruhut, "Problematika Guru Pendidikan Agama Kristen Dalam Pembelajaran Pada Masa Pandemi Covid-19 Problematics of Teachers of Christian Religion Education in Learning in the Pandemic Time Covid-19”, Jurnal Didaxei 1, no 20 (2020).
} 
mampu menjelaskan pelajaran yang diperoleh dan mempresentasikan hasilnya dihadapan guru dan siswa yang lain. Kemudian hasil atau nilai yang diperoleh tidak jauh beda dengan melakukan kegiatan belajar di sekolah. Prilaku yang ditunjukan siswa kepada guru saat pelajaran sedang berlangsung, siswa dapat menjawab, menyerap dan menerima pelajaran dari guru serta siap merespone guru dengan baik, begitu juga cepat mengembalikan tugas kepada guru. Jadi, terdapat tujuan yang jelas dari hasil pembelajaran yang dilaksankan dari rumah secara online, maka hasil yang diperoleh peserta didik sama dengan hasil yang diperoleh di sekolah secara offline. Di lihat dari kegiatan peserta didik mengikuti pembelajaran secara tatap muka maupun tidak tatap muka harus memberi hasil yang maksimal.

\section{Tips Mengatasi Problem Pembelajaran Pendidikan Agama Kristen Saat Pandemi}

Dalam pembelajaran online selama pandemi covid-19, banyak kendala yang dihadapi baik itu pendidik maupun orang tua sebagai pengajar. Pembelajaran yang semula tatap muka, akibat pandemi tersebut berubah dengan banyak dilakukan secara online. Oleh Sebab itu guru harus dituntut untuk mampu menggunakan media teknologi secara maksimal. Mungkin seorang guru pintar, pelaksanaannya juga baik, namun di sisi lain jika tidak kreatif dan melakukan inovatif dalam pengajarannya maka akan menjadi masalah. Setiap model pembelajaran di era teknologi dapat diterapkan dalam materi

\footnotetext{
${ }^{29}$ Sihotang, "Penggunaan Media Teknologi Informasi dalam Pembelajaran Pendidikan Agama Kristen di Masa Pandemi Covid-19”.
}

pembelajaran Pendidikan Agama Kristen yang dilakukan dengan salah satu atau model discovery learning, di mana pendidik dapat menuntun peserta didik untuk menemukah hal-hal baru. ${ }^{29}$ Dengan menerapkan sistem pembelajaran di era teknologi berpusat pada murid bukan kepada guru. Namun, ada beberapa hal yang harus kita perhatikan jika menerapkan Pendidikan Agama Kristen dengan baik, kreatif dan inovatif di era teknologi, yaitu: Penerapan domain desain pembelajaran di era teknologi ini telah membuka mata kita bagaimana merencanakan pembelajaran Pendidikan Agama Kristen dengan baik, menarik dan mudah dimengerti oleh siswa. Dimana setiap proses pembelajaran disesuaikan dengan keadaan yang sedang terjadi sekarang. Adapun, Witherington mengemukakan bahwa belajar adalah suatu perubahan di dalam diri kepribadian yang menyatakan diri sebagai suatu pola baru daripada reaksi yang berupa kecakapan, sikap, kebiasaan, kepandaian dan suatu pengertian. $^{30}$

Berdasarkan penjelasan tersebut maka, proses belajar masa pandemi membuat para guru bekerja lebih ekstra dalam merancang pola pengajaran yang lebih menarik supaya peserta didik tidak merasa jenuh dengan kegiatan belajar secara online. Pendidik berusaha memudahkan proses belajar-mengajar yang berlangsung dengan harapan bisa membangun semangat peserta didik dalam belajar, untuk memperoleh kepandaian, serta tingkah laku yang patut ditiru anak. Demikian pula guru berusaha mencari berbagai solusi dalam mengatasi kendala tersebut. Dengan adanya internet yang

\footnotetext{
${ }^{30}$ Syarifuddin, "Penerapan Model Pembelajaran Cooperative Belajar Dan Faktor-Faktor Yang Mempengaruhinya".
} 
menyediakan berbagai learning management system seperti Google Class room, guru dapat membuat kelas virtual untuk melaksanakan pembelajaran online di luar kelas agar peserta didik terbiasa belajar secara aktif dan mandiri dalam belajar. ${ }^{31}$ Selain itu untuk penyelesaianya bagi siswa yang berada di lokasi jauh dari jangkauan internet, maka mereka harus mencari tempat yang ada jaringan internetnya. Sekiranya sedikit data online, maka siswa berusaha mencari teman yang memiliki wi-fi di rumahnnya. Setiap kegiatan belajar di rumah hanya boleh diikuti tiga orang siswa, dengan mengikuti peraturan pemerintah untuk mencegah covid-19. ${ }^{32}$ Memakai alat teknologi dalam proses belajar online yang bervariasi sangat baik meningkatkan semangat siswa, sehingga mereka tidak bosan dan terjadi interaksi antara siswa dan guru. Dengan penggunaan media online dapat dilakukan secara live seperti whatsapp, google meet, telegram, zoom meeting dan lain-lain sehingga peserta didik dapat dipantau. ${ }^{33}$ Begitu pula melalui bahan pembelajaran yang disampaikan guru kepada murid sebelum memulai pelajaran, maka tugas terlebih dahulu di bagikan ke siswa supaya mereka bisa belajar dan menjawab apabila ditanya oleh guru saat proses pembelajaran online berlangsung agar siswa mengerti, jika ada kendala siswa dapat bertanya langsung dengan guru. Setiap tugas yang guru kirim ke siswa mempunyai limit waktu untuk mengambalikannya kepada guru, agar segera diperiksa dan pemberian nilai hasil tugas yang dikerjakan. Selain itu kelebihan dalam menggunakan media

\footnotetext{
${ }^{31}$ ManuputtyıLakoruhut, "Problematika Guru Pendidikan Agama Kristen Dalam Pembelajaran Pada Masa Pandemi Covid-19 Problematics of Teachers of Christian Religion Education in Learning in the Pandemic Time Covid-19". ${ }^{32}$ Yunita SumakulıShanti Ch N Ruata,
}

online bervariasi yang dilakukan secara lansung sehingga dapat memantau tingkah laku peserta didik sepanjang pembelajaran, dengan cara menyalakan camera. Di sisi lain orang tua juga harus terlibat saat online berlangsung agar siswa lebih fokus karena ada yang mendampinginya belajar di rumah. Sedangkan kekurangan dalam pembelajaran menggunakan media daring atau online seperti keberadaan rumah yang jauh dari jangkuan jaringan internet, data internet yang sedikit sehingga pola pembelajaran masih satu arah. Hal ini membuat peserta didik cepat jemu, proses pembelajaran belum berinteraksi baik dengan peserta didik, dimana keadaan peserta didik tidak terpantau oleh guru serta materi pembelajaran banyak diberikan berupa tugas-tugas yang banyak menyebabkan terjadi penumpukan tugas. Dan tidak semua murid memiliki hand phone, laptop dan komputer, tablet untuk belajar. Begitu pula kendala dalam penilaian diperoleh melalui bahan pengajaran yang minim, sehingga hasil yang diperoleh hanya nilai harian, nilai semester, akhir semester dan hasil ujian yang tidak maksimal. Selain itu, dalam pengamatan penulis secara empiris melihat bahwa proses pembelajaran di masa pandemi ini belum memadai dalam penggunaan media online, di sisi lain para pendidik tidak mempunyai pilihan lagi dalam pembelajaran online hanya ini salah satu cara yang dapat digunakan masa pandemi, walapun itu tidak maksimal. Tetapi dapat memutuskan penyebaran covid-19. Jadi dalam pembelajaran daring atau online memiliki plus minus dalam

\footnotetext{
"Kesejahteraan Psikologis dalam masa Pandemi COVID-19", Journal of Psychology "Humanlight" 1, no 1 (2020): 1-7.

${ }^{33}$ A Tabi, "Problematika Stay At Home Pada Anak Usia Dini Di Tengah Pandemi Covid 19”, Jurnal Golden Age 4, no 01 (2020): 190-200.
} 
dunia pendidikan.

Selain dari pada cara pembelajaran daring atau online. Pembelajaran luring juga diterapkan, pembelajaran jenis ini adalah orang tua peserta didik datang ke sekolah untuk mengambil materi dan tugas di sekolah supaya dapat dikerjakan murid di rumahnya. Begitu pula dengan menggunakan cara pembelajaran Home Living adalah guru datang mengunjungi murid-murid di rumahnya untuk datang memberikan materi dan tugas sekolah, seperti yang dilakukan oleh seorang guru bernama Nety di daerah Ngabang Landak pada tanggal 26 April 2021 melalui via telpon mengatakan bahwa para guru datang ke rumah-rumah muridnya untuk memberikan tugas sekolah yang tidak memiliki gadget serta tidak ada jangkuan jaringan internet. Di sini penulis melihat bahwa para pendidik berusaha kerja keras agar setiap murid tetap mendapat pembelajaran dari sekolah sekalipun di tengah keterbatasan dari fasilitas.

\section{Langkah-langkah Pendidikan Agama Kristen dalam pembelajaran di masa Pandemi}

Setelah memahami tips dalam mengatasi persoalan dalam pembelajar di masa pandemi, maka dalam bagian ini pentingnya langkah-langkah yang harus ditempuh, karena pembelajaran sekarang harus lebih interaktif dan inovatif dalam mengunakan metode-metode belajar, termasuk Pendidikan Agama Kristen dalam meningkatkan sikap atau prilaku yang baik terhadap pembelajaran di masa pandemi harus kokoh, kuat, teguh, tidak gampang

\footnotetext{
${ }^{34}$ Arozatulo Telaumbanua, "Peranan Guru Pendidikan Agama Kristen Dalam Membentuk Karakter Siswa", FIDEI: Jurnal Teologi
}

tergoyahkan. Pembelajaran Pendidikan Agama Kristen masa pandemi harus mempunyai waktu dan tempat agar pesan kebenaran dapat disampaikan. Melalui para pendidik Tuhan berkenan mengajar, memelihara, mendidik, serta meningkatkan komunitas milikNya lewat pendidik yang mempunyai integritas kristiani serta ingin melaksanakan pembelajaran untuk sesama serta melebarkan kerajaan Tuhan, ${ }^{34}$ sehingga setiap pendidik harus memiliki semangat dalam mengajar, keadaan yang tidak kondusif akibat pandemi bukan menjadi penghalang dalam pengajaran Pendidikan Agama Kristen. Pendidikan merupakan usaha untuk mewujudkan suasana belajar dan proses pembelajaran agar peserta didik aktif mengembangkan potensi dirinya sehingga memiliki kekuatan spiritual keagamaan, pengendalian diri, kepribadian, kecerdasan, akhlak mulia, serta keterampilan yang diperlukan dirinya dalam masyarakat. Maka dari itu melalui elemen pembelajaran Agama Kristen dapat membangun sifat/tabiat kehidupan rohani untuk menyampaikan kebenaran, iman yang kokoh di masa pandemik ini membuat peserta didik tidak merasa takut. ${ }^{35}$ Pembelajaran Agama Kristen mempunyai fungsi penting untuk meningkatkan pengalaman bersama Tuhan yang membuat iman anak tetap kuat menghadapi kondisi covid-19. Oleh karena itu orang tua memberi pengaruh positif kepada anak agar mempunyai hubungan yang baik dengan semua orang serta dekat kepada Tuhan. Begitu juga orang tua tetap membimbing anak-anak untuk dekat dengan Tuhan supaya mereka mengerti serta tidak takut menghadapi pandemi. Lewat Pembelajaran

Sistematika dan Praktika 1, no 2 (2018): 219-231. שם. 
Agama Kristen dapat mendorong semangat anak menyuarakan kepercayaannya ke dunia luar bahwa manusia tidak boleh takut karena pandemi covid-19 dan memiliki kekuatan dalam pengharapan didalam Tuhan yang membuat orang percaya baik di lingkungan keluarga atau pun lingkungan sosial supaya dapat menunjukan sikap hidup yang tidak cemas dan ketakutan terhadapa pandemi. Melalui keluarga dapat mengkampanyekan model kehidupan yang positif dan kerohanian di lingkungan masyarakat saat ini. ${ }^{36}$ Lanjutnya Arifianto mengatakan bahwa pembelajaran Agama Kristen merupakan cara untuk mendidik anak kearah yang baik menuju pribadi yang berakhlak mulia dan bermoral. ${ }^{37}$ Dengan terjadinya peristiwa covi-19 keluarga memiliki peran yang bearti memotivasi dan menumbuhkan kerohanian anak supaya masa seperti ini tidak membuat mereka cemas. Oleh sebab itu pendidik, orang tua dan murid tetap bersatu memerangi penyebaran covid-19 dan menaruh harapan kepada Tuhan dalam menghadapi keadaan dunia sekarang. Dari hal tersebut maka orang tua dalam keluarga sangat penting memberi arahan pembelajaran Pendidikan Agama Kristen serta bertindak secara aktif, lingkungan keluarga merupakan wadah yang tepat walaupun dalam lingkup terkecil di masyarakat untuk membangun asas yang kuat bagi semangat belajar anak. ${ }^{38}$ Oleh karena itu orang tua memiliki tugas bagi perkembangan kecerdasan spiritual anakanak tersebut sangat penting melalui pembelajaran Pendidikan Agama Kristen. Di sisi lain Pendidikan Agama Kristen merupakan pusat dari proses pembelajaran untuk meningkatkan kerohanian iman

\footnotetext{
${ }^{36}$ Yonatan Alex Arifianto, "Pentingnya Pendidikan Kristen dalam Membangun Kerohanian Keluarga di Masa Pandemi Covid-19”, Regula Fidei Jurnal Pendidikan Agama Kristen 5, no 2 (2020): 94-106. שם.
}

Kristen.

\section{Upaya-upaya Orang Tua dalam Menangani Psikologi Anak dimasa Pandemi}

Bagi penulis, orang tua harus bisa mengimplementasikan upaya dalam menangani psikologi anak. Orang tua perlu melibatkan anak dalam kegiatan-kegiatan kerohanian supaya mengalami perkembangan yang baik dalam berpikir dan tidak merasa takut menghadapi pandemik, seperti melibatkan anak-anak melalui ibadah secara online serta mendampingi anak dalam belajar firman Tuhan. Hal ini dilakukan untuk mewujudkan pertumbuhan psikologi anak yang baik, maka orang tua memiliki tanggung jawab kehidupan setiap anak, sebab waktu anak lebih banyak dengan keluarga. ${ }^{39}$ Penting sekali kehadiran orang tua bagi anak dimasa pandemi ini, apalagi dalam kegiatan-kegiatan yang dilakukan secara online. Apabila orang tua mengetahuinya serta mendalaminya, hingga secepatnya mempererat hubungan yang baik dengan anak. Maka, psikologi anak tidak mengalami kesulitan dalam kondisi pandemi ini. Begitu pula orang tua harus mengenali metode terbaik menguasai psikologi anak. Ada beberapa hal tindakan Orang tua untuk memahami psikologi anak, agar anak dapat bertumbuh baik dalam psikologinya, yaitu: mengamati gerak gerik anak dalam memahami psikologi anak orang tua perlu mengamati sebuah kemampuan untuk mengenali diri anak dengan baik. Jika orang tua dapat mengamati anak saat bermain, meminta hal

\footnotetext{
${ }^{38}$ Ibid.

${ }^{39}$ Desi Sianipar, "Peran Pendidikan Agama Kristen

Di Gereja Dalam Meningkatkan Ketahanan

Keluarga", Jurnal Shanan 4, no 1 (2020): 73-92.
} 
tertentu, cara mereka bereaksi terhadap situasi, interaksinya dengan orang lain, dan lainnya. Maka orang tua dapat mengenal banyak tentang kepribadiannya secara keseluruhan melalui cara ini. Orang tua juga dapat memberikan respon atas pemahaman tersebut.

Dengan demikian dapat mendukung apa yang mereka sukai, bagaimana mereka bertindak, dan hal-hal lainnya. Anak memiliki hal-hal menonjol pada dirinya, maka jangan mencoba untuk membandingkannya dengan anak-anak lain. Sebagai seorang pendengar yang baik disaat berkomunikasi orang tua perlu menjadi mentor yang baik terhadap anak. hal Ini, sangat baik untuk perkembangan psikologi anak melalui komunikasi yang baik agar anak dapat mengekspresikan dirinya. Ekspresi dan bahasa tubuh yang mereka gunakan. Orang tua dapat mengetahui dan mengukur perasaan emosi anak. ${ }^{40}$ Orang tua tidak hanya harus mendengarkan, tetapi juga dapat memberi masukan bagi anak. Ini menjadi bukti bahwa mereka didengarkan dan diperlakukan dengan serius. Di sisi lain orang tua juga harus memastikan lingkungan keluarga yang tepat bagi anak supaya mereka merasa nyaman di tempat ia dibesarkan ikut ambil bagian dalam pembentukan perilaku dan sikap anakanak. ${ }^{41}$ Dimana lingkungan dapat mempengaruhi perkembangan otak anak, termasuk keterampilan dan kognitifnya. Dengan memperhatikan perilaku anak pada lingkungannya, termasuk jenis orang yang

\footnotetext{
40 Talizaro Tafonao, "Peran Guru Dalam Menangani Perilaku Menyimpang di Kalangan Siswa Millenial", בתוך Implementasi Pendidikan Agama dan Pendidikan Karakter (Tangerang: Media Edukasi Indonesia, 2019), 164-179.

${ }^{41}$ Farida Rohayani, "Menjawab Problematika Yang Dihadapi Anak Usia Dini di Masa", Qawwam.
}

berinteraksi dengannya. Perhatikan juga apakah sikapnya berbeda di lingkungan rumah dibandingkan saat berada di lingkungan sekolahnya.

Memberikan edukasi yang baik dalam perkembangan anak sangat tepat karena setiap orang tua merindukan anakanaknya bertumbuh dalam psikologinya, ${ }^{42}$ hal ini juga perlu dilakukan oleh orang tua yaitu memberikan edukasi yang baik kepada anak melalui kehidupannya sebagi orang tua. Supaya orang tua memahami berbagai tahapan perkembangan anak serta orang tua lebih tahu lagi seberapa jauh anak tersebut telah berkembang. Menyediakan waktu untuk menambah wawasan terhadap hal baru mengenai perkembangan anak melalui buku, jurnal online, ataupun melalui bincang-bincang dengan seorang spesialis. Lebih baik orang tua mengetahui perkembangan anak daripada tidak sama sekali dan menganggap semuanya baikbaik saja. adapun orang tua harus memberi waktu yang berkualitas bagi anak. memberi waktu yang terbaik dan lebih berharga dari barang-barang yang orang tua belikan baginya. Tetapi hal ini, banyak dari orang tua saat ini yang terlalu sibuk dengan pekerjaan sibuk, sehingga tidak ada waktu untuk anak bahkan jarang menghabiskan waktu dengan anak. Jika orang tua memberi waktunya untuk anak, maka orang tua akan benar-benar memahami perkembangan psikologinya. Hal yang mudah dapat mengisi waktu dengan membahas banyak hal, bermain bersama dirumah, mengisi waktu dengan berbagai kreativitas. Oleh

Journal For Gender Mainstreaming 14, no 1 (2020): 29-50.

${ }^{42}$ Talizaro TafonaoıYosua Budi Ristiono, "Peran Guru Agama dalam Meningkatkan Mutu Pembelajaran dengan Bantuan Multimedia”, Jurnal Komunikasi Pendidikan 4, no 1 (2020): 9. 
karena itu, orang tua dapat memahami psikologi anak saat menghabiskan waktu bersama dengan anak. Terjadi perkembangan yang baik dan positif dalam diri anak, karena kebersamaannya dengan orang tua yang mengarahkan pada hal-hal yang membangun hubungan serta bersikap terbuka dan perhatian bila berhadapan bersamanya. Oleh karena itu, upaya yang dilakukan orang tua tidak akan sia-sia dalam membentuk psikologi anak yang baik saat menghadapi pandemi. Waktu anak bersama orang tua saat pandemi ini sangat banyak, maka dari itu dalam keluarga harus bisa menciptakan suasana keluarga yang nyaman dan menyenangkan, sehingga psikologi anak dapat terbentuk dengan baik dalam menghadapi situasi pandemi saat ini, secara psikis mental anak menjadi kuat. Psikologi anak adalah bidang riset mengenai tumbuh kembang mental, emosional serta sikap anak. Serta ada anak yang belum mengalami perkembangan dalam kerohaniannya, hal ini disebabkan beberapa faktor yaitu tidak adanya motivasi untuk beribadah secara online dan suasana yang kurang mendukung untuk serius beribadah, faktor lainnya ialah tidak ada mendampingi dan mengawasi anak dalam ibadah online. $^{43}$ Kalau orang tua mengetahuinya serta mendalaminya, hingga secepatnya mempererat hubungan yang baik dengan anak. Pemahaman orang tua terhadap psikologi anak bisa berdampak patal pada pembuatan karakter anak saat sebelum mereka menuju dewasa. Perihal itu pula nyatanya dapat mempengaruhi pertumbuhan fisik, kognitif, emosional serta sosial mereka. Berarti untuk orang tua harus mengenali metode terbaik menguasai

\footnotetext{
${ }^{43}$ Arifianto, "Pentingnya Pendidikan Kristen dalam Membangun Kerohanian Keluarga di Masa Pandemi Covid-19".

${ }^{44}$ Talizaro Tafonao, "Peran Pendidikan Agama
}

psikologi anak. Ada beberapa hal tindakan orang tua untuk memahami psikologi anak, agar anak dapat bertumbuh baik dalam psikologinya, yaitu mengamati gerak gerik anak dalam memahami psikologi anak orang tua perlu mengamati sebuah kemampuan untuk mengenali diri anak dengan baik. ${ }^{44}$

Lingkungan yang tepat sangat berpengaruh besar terhadap dalam pembentukan perilaku dan sikap anak-anak. Sebab lingkungan atau tempat tinggal anak sangat memengaruhi perkembangan otak anak, termasuk keterampilan dan kognitifnya. Dengan memperhatikan hal ini maka anak-anak menjadi pribadi yang dewasa sesuai perkembangannya. Oleh karena itu perlu memiliki pengetahuan yang baik dalam memahami perkembangan anak karena setiap orang tua merindukan anakanaknya bertumbuh baik secara psikologi, hal ini juga perlu dilakukan oleh orang tua yaitu memberikan edukasi yang baik kepada anak melalui kehidupannya sebagai orang tua. Supaya orang tua memahami berbagai tahapan perkembangan anak serta orang tua lebih tahu lagi seberapa jauh anak tersebut telah berkembang. Menyediakan waktu untuk menambah wawasan terhadap hal baru mengenai perkembangan anak melalui buku, jurnal online, ataupun melalui bincang-bincang dengan seorang spesialis. Lebih baik orang tua mengetahui perkembangan anak daripada tidak sama sekali dan menganggap semuanya baikbaik saja.

\section{KESIMPULAN}

Berdasarkan pembahasan di atas,

Kristen dalam Keluarga Terhadap Perilaku Anak", Edudikara: Jurnal Pendidikan dan Pembelajaran, Vol 3 (2), 2018 ISSN 2541-0261 3, no 2 (2018): 121-133. 
maka penulis menyimpulkan bahwa pembelajaran secara online merupakan cara yang tepat untuk dilakukan dimasa pandemi demi memutuskan penyebaran covid 19. Tetapi disisi lain pembelajaran online menuai berbagai problem yang dihadapi oleh peserta didik sebagimana penjelasan dalam artikel ini. Oleh karena itu hendaknya para guru Agama Kristen dan orang tua memiliki sinergitas dalam menghadapi terjadinya dampak psikologi pada anak. Dalam kajian ini penulis melihat bahwa keterlibatan orang tua dalam mendampingi anak selama pembelajaran di masa pandemi masih belum maksimal, sehingga tulisan ini banyak menyoroti aktivitas dari orang tua dalam mendidik dan mendampingi anak selama belajar di rumah.

Tulisan ini hadir sebagai sumbangsih pemikiran baru dalam memperhatikan berbagai problem dalam pembelajaran Pendidikan Agama Kristen dimasa pandemi serta menjadi referensi bagi para peneliti berikutnya. Penulis mengakui bahwa selama penyusunan artikel ini memiliki berbagai kekurangan dari berbagai sisi baik segi narasi, kajian, sumber dan data.

\section{DAFTAR PUSTAKA}

Agung, Ivan Muhammad. "Memahami Pandemi Covid-19 Dalam Perspektif Psikologi Sosial". Psikobuletin:Buletin Ilmiah Psikologi 1, no. 2 (2020): 68-84.

Arifianto, Yonatan Alex. "Pentingnya Pendidikan Kristen dalam Membangun Kerohanian Keluarga di Masa Pandemi Covid-19”. Regula Fidei Jurnal Pendidikan Agama Kristen 5, no. 2 (2020): 94-106.

Buana, Riska Dana. “Analisis Perilaku Masyarakat Indonesia dalam Menghadapi Pandemi Covid-19 dan Kiat
Menjaga Kesejahteraan Jiwa". Sosial dan Budaya, Fakultas Syariah dan Hukum Universitas Islam Negeri (UIN) Syarif Hidayatullah Jakarta 53, no. 9 (2017): 1689-1699.

Cahyati, Nika, ıRita Kusumah. "Peran Orang Tua Dalam Menerapkan Pembelajaran Di Rumah Saat Pandemi Covid 19”. Jurnal Golden Age, Universitas Hamzanwadi 04, no. 1 (2020): 152-159.

Darmalaksana, Wahyudin. "Metode Penelitian Kualitatif Studi Pustaka dan Studi Lapangan”. Pre-print Digital Library UIN Sunan Gunung Djati Bandung (2020): 1-6.

Firman, Firman, ISari Rahayu. "Pembelajaran Online di Tengah Pandemi Covid-19". Indonesian Journal of Educational Science (IJES) 2, no. 2 (2020): 81-89.

Hutapea, Rinto Hasiholan. "Kreativitas Mengajar Guru Pendidikan Agama Kristen Di Masa Covid-19". Didache: Journal of Christian Education 1, no. 1 (2020): 1.

KementrianKesehatanRI. "Dokumen resmi". Pedoman kesiapan menghadapi COVID19 (2020): 0-115.

Khalimah, NS. "Peran orang tua dalam pembelajaran daring di mi darul ulum pedurungan kota semarang tahun pelajaran 2020/2021 skripsi” (2021).

Kinasih, Tindhi. "Manajemen Peningkatan Kemampuan Guru PAI Dalam Penggunaan Metode Pembelajaran Di SMP Negeri 1 Nusawungu Kecamatan Nusawungu Kabupaten Cilacap”. IAIN Purwokerto, 2018.

Kompas.com. "Dampak Psikologis pada Anak yang Sekolah dari Rumah", 2020.

Mahmudah, R, S. "Pengaruh pembelajaran daring terhadap psikologis siswa terdampak social distancing akibat covid19". Jurnal Al-Mau'izhoh Vol. 2. No, no. 1 (2020): 207-213.

Manuputty, Prilly, ıNovia Lakoruhut. "Problematika Guru Pendidikan Agama Kristen Dalam Pembelajaran Pada Masa Pandemi Covid-19 Problematics of 
Teachers of Christian Religion Education in Learning in the Pandemic Time Covid19”. Jurnal Didaxei 1, no. 20 (2020).

Phelps, Chavez, ILinda L. Sperry. "Children and the COVID-19 Pandemic". Psychological Trauma: Theory, Research, Practice, and Policy 12 (2020): 73-75.

Rohayani, Farida. "Menjawab Problematika Yang Dihadapi Anak Usia Dini di Masa". Qawwam: Journal For Gender Mainstreaming 14, no. 1 (2020): 29-50.

Rosihuddin, Muhammad. "'Pengertian Problematika Pembelajaran”, 2012.

Sadikin, Ali, Afreni Hamidah, Kampus Pinang, Masak Jl, Jambi Ma, Bulian Km, Mendalo Indah, Kec Jaluko, Kab Muarojambi-jambi Kode’Pos Indonesia. "Pembelajaran Daring di Tengah Wabah Covid-19 ( Online Learning in the Middle of the Covid-19 Pandemic )" 6, no. 1 (2020): 214-224.

Sakerebau, Junier. "Memahami Peran Psikologi Pendidikan Bagi Pembelajaran". BIA': Jurnal Teologi dan Pendidikan Kristen Kontekstual 1, no. 1 (2018): 96-111.

Setiawan, Deny. "Peran Pendidikan Karakter Dalam Mengembangkan Kecerdasan Moral". Jurnal Pendidikan Karakter 1, no. 1 (2013): 53-63.

Sianipar, Desi. "Peran Pendidikan Agama Kristen Di Gereja Dalam Meningkatkan Ketahanan Keluarga". Jurnal Shanan 4, no. 1 (2020): 73-92.

Sihotang, Hermanto. "Penggunaan Media Teknologi Informasi dalam Pembelajaran Pendidikan Agama Kristen di Masa Pandemi Covid-19". IMMANUEL: Jurnal Teologi dan Pendidikan Kristen 1, no. 2 (2020): 63-75.

Sumakul, Yunita, IShanti Ch N Ruata. "Kesejahteraan Psikologis dalam masa Pandemi COVID-19". Journal of Psychology "Humanlight" 1, no. 1 (2020): 1-7.

Syarifuddin, Ahmad. "Penerapan Model Pembelajaran Cooperative Belajar Dan Faktor-Faktor Yang Mempengaruhinya".
Ta'dib:Journal of Islamic Education (Jurnal Pendidikan Islam) 16, no. 01 (2011): 113-136.

Tabi, A. "Problematika Stay At Home Pada Anak Usia Dini Di Tengah Pandemi Covid 19”. Jurnal Golden Age 4, no. 01 (2020): 190-200.

Tafonao, Talizaro. "Peran Guru Dalam Menangani Perilaku Menyimpang di Kalangan Siswa Millenial". בתוך Implementasi Pendidikan Agama dan Pendidikan Karakter, 164-179.

Tangerang: Media Edukasi Indonesia, 2019.

. "Peran Pendidikan Agama Kristen dalam Keluarga Terhadap Perilaku Anak". Edudikara: Jurnal Pendidikan dan Pembelajaran, Vol 3 (2), 2018 ISSN 2541-0261 3, no. 2 (2018): 121-133.

Tafonao, Talizaro, ıYosua Budi Ristiono. "Peran Guru Agama dalam Meningkatkan Mutu Pembelajaran dengan Bantuan Multimedia”. Jurnal Komunikasi Pendidikan 4, no. 1 (2020): 9.

Telaumbanua, Arozatulo. "Peranan Guru Pendidikan Agama Kristen Dalam Membentuk Karakter Siswa". FIDEI: Jurnal Teologi Sistematika dan Praktika 1, no. 2 (2018): 219-231.

Thahir, Andi. "Psikologi Belajar Buku Pengantar dalamm Memahami Psikologi Belajar" (2014): 291.

Wardani, Anita, IYulia Ayriza. “Analisis Kendala Orang Tua dalam Mendampingi Anak Belajar di Rumah Pada Masa Pandemi Covid-19". Jurnal Obsesi : Jurnal Pendidikan Anak Usia Dini 5, no. 1 (2020): hal 778 (772-782).

Wati, Ita Tri Puspita. "Implementasi Kegiatan Belajar Mengajar Pada Sekolah Inklusif di SMPN 29 Surabaya". Jurnal Pendidikan 1, no. 1 (2013): 1-10.

Zaluchu, Sonny Eli. "Strategi Penelitian Kualitatif dan Kuantitatif di dalam Penelitian Agama". Evangelikal: Jurnal Teologi Injili dan Pembinaan Warga 
Problem Pembelajaran Pendidikan Agama Kristen Dimasa Pandemiterhadap Psikologi Anak | $\mathbf{1 5 5}$

Jemaat 4, no. 1 (2020): 28-38. 
156 | SANCTUM DOMINE: Jurnal Teologi, vol. 10, no. 2 (2021) 